\title{
The Effects of Mobbing on Organizational Cynicism: A Study on Hotels in Turkey
}

\author{
Elbeyi PELIT (Corresponding Author) \\ Assoc. Prof.Dr. in Faculty of Tourism, Afyon Kocatepe University, Afyonkarahisar, \\ Turkey \\ E-mail: elbeyipelit@aku.edu.tr

\begin{abstract}
Nil PELIT
Instittitues of Social Sciences,

Tourism and Hotel Management, Afyon Kocatepe University, Afyonkarahisar,

Turkey

E-mail: nil_lin@hotmail.com
\end{abstract}

Doi:10.5296/ijhrs.v4i1.4996 URL: http://dx.doi.org/10.5296/ijhrs.v4i1.4996

\begin{abstract}
The aim of this study is to determine the effects of the hotel employees' mobbing perceptions on organizational cynicism. In this respect, employees' mobbing perceptions and attitudes related to organizational cynicism are evaluated separately, and then through putting forth the effect of mobbing on organizational cynicism on the sample of hotel business employees in Turkey. In this research, survey technique was utilized as a data collecting method, also the relevant mobbing and organizational cynicism scales were utilized. Survey way applied to 936 people selected through stage sampling method from employees of the five star hotel in Turkey which constitute the population of this research, and data collected for the aim of this study was analyzed and interpreted.

According to the results of this research, it was determined that when hotel employees' mobbing perceptions are considered in general, the highest mobbing perception is in "self-realization and attacks intended for communication formation" dimension; when their attitudes on organizational cynicism are considered in general, organizational cynicism with the highest average is behavioral cynicism. On the other hand, relations between employees' mobbing perceptions and attitudes on organizational cynicism have been found significant in this research, also it is achieved that mobbing increases organizational cynicism.
\end{abstract}

Keywords: Mobbing, organizational cynicism, employees' attitudes, hotels, Turkey.

\section{Introduction}

Mobbing and organizational cynicism, exist as a resistance against improvement of the organization and severely damaging the organization, two of the organizational problems, 
causes organization to experience various results, such as loosing successful and talented staff, increasing the revolution speed of the employees, reducing the organizational loyalty and credibility, increasing discontinuities, alienating to job and disobedience (Leymann, 1990; Zapf et.al., 1996; Davenport et.al., 2003; Dean et.al., 1998; Pitre, 2004; Arabac1, 2010). In this respect, organizations should develop strategies for governing mobbing and organizational cynicism, and minimize their impacts. This issue is also vital for effectiveness of hotels', one type of service businesses. In order to cover the needs of the clients, satisfaction of employees, who are rendering their skills, efforts and time against a certain amount of money and has expectations from their employed organizations, is vital in order to prevent mobbing and organizational cynicism before it exists. It especially causes works require special efforts in the service businesses, where employee performance has the leading role, and employees need more motivation while performing their works. Being services a complicated process (being simultaneous, discrete, etc.) and having problems due to organizational reasons, make works more difficult for the employees and even cause them to show some negative attitudes to their organizations. In this respect, problems due to corporation policies and applications in general cause mobbing and organizational cynicism concepts to exist, and set stage for employee performance and motivation reduction, and alienation against organization and even quitting.

In order to maintain employees to work more efficient within a healthier work environment with high motivation and to minimize possible damages to the companies, first of all employee's mobbing perceptions and organizational cynicism attitudes should be determined and policies for removal should be developed. It is possible to mention that also organizational cynicism, which causes nervous and emotional breakdowns and causes individuals to have psychological/psychosomatic reactions, such as depression, insomnia, disappointment, anxieties and nervousness (Brandes, 1997: 41), causes similar results on the individual compared to mobbing. Besides, one can say that like mobbing, organizational cynicism also affects physical health of the individual in addition to the mental health, and increases possibility of heart and venous diseases (Eaton, 2000: 7; Kalağan, 2009: 80). Furthermore, it is possible that employees with high degree cynic attitudes might have feelings, such as insecurity, anxiety, worries and angriness, and even experience depression or other psychosomatic problems, and cause them to apply mobbing against other employees.

On the other hand, mobbing stages and processes include factors, which shall cause persons to develop cynic attitudes within organizational environment. In this respect, research focused main issue is to determine the level of this relation and aim of this research is to determine impacts of mobbing perceptions of hotels' employees to organizational cynicism. In this respect, current status related with subject matter is revealed by means of a study, performed on hotels' employees, one of the most important company types of tourism companies, and aimed to contribute in connection with removal of mobbing perceptions and organizational cynicism related attitudes of employees, which might reveal/reveal negative results in connection with organizational efficiency and productivity. 


\section{Literature review}

When one inspects the background process; mobbing term, which is firstly used to define abuse attitude of animals among themselves or an alien out of the herd by Lorenz on 1960, was also used to define the bullying abuse events, seen among students in the school, by Heinmann on 1972 afterwards. Leymann (1996), who stated that similar attitudes are also observed at work, preferred to use this term for negative attitudes, which are applied repeatedly, intentionally or unintentionally by one or more employees at work, and which are galling, upsetting and causing problems, reducing work performance and disturbing (Einarsen, 1999: 17; Smith et. al., 2003: 177; Davenport et.al., 2003: 2). Accordingly, Leymann (1990) mentioned that "bullying" evokes physical assault, violence and threat, and underlined that despite physical violence is being experienced very rarely during damaging, destructive actions at work, same concept might turn into physical assault actions at school. Therefore, Leymann $(1990 ; 1996)$ had suggested to use "bullying" term for school organizations and "mobbing" term for offices, and this concept is used as per Leymann's (1990) suggestions in this study.

In short; mobbing activities, which are defined as all kinds of rude attitudes and might cause lots of negative results up to suspension of victim persons with disturbance of employees' psychological and physical health within the organization (Zapf et. al., 1996: 1177), exist due to mobbing applier and victim person's psychology, personality, subjected conditions, organizational and administrative and other (economical crisis, changes etc.) reasons, and along with their negative impacts, it includes a process, progressing till quitting persons work (Davenport et. al., 2003: 24). Leymann (1990), had determined 45 activities to find out the presence of the mobbing in 5 dimensions (activities on the possibilities of the person to communicate adequately, activities on the possibility of the victim to maintain social contacts, activities on the possibilities of the victim to maintain his/her personal reputation, activities on the occupational situation of the victim, activities on the physical health of the victim) and list as LIPT (Leymann Inventory of Psychological Terrorization). On the other hand, another organizational attitude issue, which becomes a very important organizational problem with revealing similar results on both individuals and organizations, is organizational cynicism. Roots of organizational cynicism, described as negative attitudes including three dimensions in connection with beliefs, affects and behaviors (Dean et.al., 1998: 345) developed by person against his/her employed organization, reach till general cynicism. It is possible to see first studies related with cynicism in "Minnesota Multidirectional Personality Inventory", developed on 1940s, Cook and Medley (1954)'s "Cynic Hostility" scales. In this respect, one of the first studies on organizational cynicism was implemented in police organizations by Niederhoffer (1967). Organizational cynicism, which is a concept intensely researched especially after 1990s within organizational attitude area despite it has a detailed background, revealed along with the book, prepared by Kanter and Mirvis (1989) for the purpose of determining why cynicism spread in the organizations, (James, 2005: 24).

Basic theories, on which organizational cynicism concept is based and not depending on a single theory, when it is considered conceptually, are expectancy theory, attribution theory, attitude theory, social exchange theory, emotional events theory and social motivation 
theory. Organizational cynicism concept is the "negative attitudes of individual in connection with his/her organization" and thought of organization deprives honesty and integrity (Dean et al., 1998; Kalağan, 2009). For the purpose of determining whether organizational cynicism is present within companies or not, organizational cynicism is being inspected on three dimensions at the scale, developed by Dean et al. (1998). The three dimensions, including negative attitudes referred on the description of organizational cynicism are conceptualized in form of a belief that organizations lacks integrity, a negative affect toward the organization and, tendencies to disparaging and critical behaviors against organization (Dean vd., 1998; Mantere ve Martinsuo, 2001; Kutanis and Çetinel, 2009; Kalağan and Güzeller, 2010; Özler vd. 2010; Pelit and Ayduğan, 2011). Organizational cynicism has impacts, which reduces the efficiency and productivity of the organizations, and causing severe financial and moral losses. Accordingly, although it is possible to mention about the wide range results of organizational cynicism, such as dissatisfaction from job, decrease on loyalty to organization, sabotage, robbery, fraud, increase on organizational reduce, increase on quitting rates, reduce on employee turnover rate, increase on firing from work, alienation to work and reduce on organizational performance and citizenship feeling, in addition to cause emotional problems in the organizations, it can also cause important physiological problems on the employee (missing working days due to sickness of the employee, quitting job, reduce on performance, etc.) and accordingly results, which can be deemed as serious losses in connection with the organization (Eaton, 2000). These above mentioned reasons is showing parallelism with the individual impacts, seen on the employees subjected to the mobbing, and in case of excessive levels of organizational cynicism, it is possible to say that it can damage employee as much as an office terror, mobbing.

It draws attention that studies, implemented on mobbing (Einarsen et. al., 1998; McMahon 2000; Hoel and Einarsen, 2003; Piñuel y Zabala and Oñate Cantero, 2002; Çalışkan, 2005; Demirçivi, 2008; Çarıkçı and Yavuz, 2009; Hutchinson et. al., 2009; Avcı and Kaya, 2010; Karcioğlu and Akbaş, 2010; Mkono, 2010; Pelit and Kılıç, 2012), are mostly focused on the services sector. During the studies, implemented in this area, it is seen that findings in connection with presence of mobbing concept in the companies and relation with some working attitudes (such as negative impact of the mobbing on employee performance and productivity, mobbing perceptions of the resort hotel employees are higher, as well as age and position in the company variables have impact on the mobbing perceptions of the employees) are obtained. Thus, during a study, implemented by European Work Life Arrangement Institution (2004) and including various European countries, it is revealed that mobbing exists in the companies and entities, such as transportation, communication, hotel, catering and restaurant, training and healthcare, within the service sector (Kaya 2009).

In case of experiencing mobbing activities, which might be deemed from important organizational impacts of developing attitudes related with organizational cynicism by employees, within the companies, it shall cause employee to depart from his/her employed company and especially to disturb faith to and credibility of companies, which is silent against this issue. Therefore, these two issues of the organizational attitude related with each other in connection with negative impacts during the experienced period within the organizations should be handled for the purpose of taking measures, and relation or impact 
level should be determined and revealed. So, it is possible to say that activities, in which stages, included by content and dimensions in general of the mobbing process (occurrence of conflict, harassment and stamping, inclusion of management to the process, wrong description and firing from job) are occurring, is also including the activities in connection with experiencing the organizational cynicism alone. Mutual impacts of the above mentioned two concepts, which include similar results in connection with the damages suffered by the employees and companies, are listed on the Table 1 in general.

Table 1. Effect of mobbing and cynicism on organizations

\begin{tabular}{|c|c|}
\hline Personnel Effects & Organizational Effects \\
\hline Increase in burnout & Increase in turnover rate \\
\hline Depression & Decrease in organisational performance \\
\hline Fear of losing the jop & Decrease in organisational commitment \\
\hline Attention deficiency & $\begin{array}{l}\text { Decrease in confidence to the organization and } \\
\text { managers }\end{array}$ \\
\hline Physicial problems & Decrease in attendence \\
\hline Alineation to organisation & Increase in costs \\
\hline Decrease in motivation & $\begin{array}{l}\text { Additional costs by new recruitments and adaptaion } \\
\text { process }\end{array}$ \\
\hline Decrease in performance & Early retirement and severence payment demands \\
\hline Dissatisfaction & Organizational image problemsi \\
\hline $\begin{array}{l}\text { Increase in intention to quit the } \\
\text { job }\end{array}$ & Decrease the quality in production \\
\hline $\begin{array}{l}\text { Decrease in organisatioanl } \\
\text { citizenship }\end{array}$ & Increase in humiliating the organization \\
\hline Decrease in confidence & To lose the successfula and hardworking employees. \\
\hline
\end{tabular}

When studies within the literature related with mobbing are investigated (Leymann, 1990; 1996; Zapf, 1999; Mcmahon, 2000; Einarsen et. al., 2001; Naime, 2003; Ferrari, 2004; Einarsen, 2005; Tinaz, 2006; Crawshaw, 2009; Eser, 2009; Hutchinson et. al., 2009; Osif, 2010; Tetik, 2010) briefly, initial studies aimed to describe the concept, to determine preceding and succeeding things, and to determine their impacts on companies and employees, and on the subsequent studies, it is focused to investigate the relations of the issue with other organizational attitude issues (Vartia, 1996; Raver, 2004; Tehrani, 2004;

Hallberg and Margaretha, 2006; Sürgevil et. al., 2007; Pedro et. al., 2008; Pelit and Kılıç, 2012). When organizational cynicism concept oriented literature is investigated (Sloterdijk, 1983; Kanter and Mirvis, 1989), while it is seen that studies were performed for the purpose of introducing the general cynicism to the literature and revealing its impacts on 1980s, it is possible to mention that studies related with organizational cynicism progressed during 1990s and afterwards in form of description of organizational cynicism, development of its scales, revealing its dimensions (belief, affect and behavior) and reasons (Wanous et.al., 1994; Vance et. al., 1996; Brandes, 1997; Dean et. al., 1998; Brandes et. al., 1999; Davis and Gardner, 2004; Pitre, 2004; Naus, 2007).

Hotels, which are activating within the tourism sector, have unique management and operation understandings in connection with their structures and characteristics. In particular, 
it is possible to mention that rendering services in connection with the expectation of the customers and protecting these via certain standards are directly related with the performances of the employees. In the service companies, where employee motivation and performance plays the leading role, and when relations and communication among employees realizes more frequently and intensely, it shows itself in various types of negative impacts, such as experiencing mobbing in the office (Köse, 2006), and disturbance of works, reduce on quality, and damaging to the positive image. Having intense and complicated structured relations between employees can form a ground for a working environment, appropriate to the mobbing, harassment, bullying and other violence attitudes within the organization (Yücetürk and Öke, 2005). In addition to this, employees within the tourism companies, who come from different social structures has a considerable importance on the formation of mobbing. In the major part of the tourism companies, employees from different cultures, regions and nations are being gathered. Therefore, tourism companies are being shown among the working environments, where differences between employees are felt more intensely. In the organizations, composed of individuals with different beliefs, values, attitudes and different cultural codes, with the effect of the environment with higher tense in connection with the excessive competition of working life, differences between employees can form grounds to develop attitudes in form of excluding and alienate each other. This might cause in house severe and hard to solve disputes to turn into mobbing attitudes (Heames ve Harvey, 2006). In the companies, where ethnical minority or immigrant individuals from different cultures are intensely employed, mobbing attitudes, such as insulting/harassing these persons, can be applied (Hoel and Einarsen, 2003; Kaya, 2009). Especially for the tourism companies, where one on one relations with customers are performed, although mobbing attitudes mostly affect the victim individual, whereas it also affects other employees, company and customer with reduce on service quality (Güngör, 2008). In this respect, ignoring presence of mobbing or failure to prevent environments, where it can occur, shall prepare the ground for increasing the attitudes of employees in connection with organizational cynicism in the future, and reducing job satisfactions and loyalties (Brandes et.al. 1999) as well as occurrence of bigger problems (quitting jobs by victims, getting psychological treatment, increasing employee turnover rate, reducing service quality, damaging company image and lots of other negative impacts).

On the subject related literature, impacts of organizational cynicism, which causes tangible and moral huge losses for the companies in addition to its negative impacts on the employees, on the organizations as well as employees; are listed as reduce on the trust to organization (Andersson, 1996; Andersson and Bateman, 1997; Pugh et.al., 2003; Kalağan, 2009; Rubin et.al., 2009; Bashir et. al., 2011), reduce of organizational citizenship behavior and justice (Fitzgerald, 2002; Pugh et. al., 2003; Wilkerson et.al., 2008; Özler et.al., 2010), psychological contract violations (Johnson and O'Kelery 2003; Bashir et. al., 2011), resisting to organizational alteration, conflict between persons, discontinuity, reduce of trust to the leader-disrespect, increase on turnover rate, reduce of loyalty to work-organization, disobeying to rules, exhaustion (Reichers et. al., 1997; Wanous et. al., 2000; Rubin et. al., 2009; Tükeltürk et. al., 2009), sabotage, theft, fraudulency, alienation (Dean et. al., 1998; Özgener et. al., 2008) and it is underlined that this condition has negative effect on the 
productivity, decisiveness, image, productive and effective operation of the organization. In addition to this, when subject related studies investigated (Kanter and Mirvis, 1989; Dean et., 1998; Eaton, 2000; Delken, 2004; James, 2005; Cartwright and Holmes, 2006; Byrne and Hochwarter, 2007; Efilti et.al., 2008; Altınöz et. al., 2010; Pelit and Ayduğan, 2011) are investigated, one can put forward that impact level of demographical variables on the organizational cynicism varies, and general opinion is "some personal/demographical factors have no impact on the organizational cynicism. On the other hand, the variables in the studies of mobbing concept within the organizational environment, although it is possible to note that especially mobbing has generally negative impact/relation on the organizational climate (Mercan, 2007; Yılmaz et.al., 2009), leadership (Cemaloğlu, 2007), personality (Deniz, 2007; Avcı and Kaya, 2010; Deniz and Ünsal, 2010), work satisfaction (Çalışkan and Tepeci 2008; Doğan, 2009; Karcıoğlu and Akbaş, 2010), intention to leave the job (Çakır, 2006; Özaralı and Torun, 2007), organizational citizenship (Raver, 2004; Poyraz and Aksoy, 2012), exhaustion (Sürgevil et.al., 2007), efficiency (Yeşiltaş and Demirçivi, 2009), organizational loyalty (Tengilimoğlu et.al., 2010) as well as relations, one can realize that there is a lack of studies in connection with its impacts on organizational cynicism, an unwanted conditions related with organizations and composing one of the main subjects of the study. Such as there is no study, which reveals this relation level in connection with tourism and hotels. In this respect, the issue that mobbing concept, of which negative impacts are determined on the above mentioned organizational behavior issues, might also be effective on organizational cynicism, which has similar impacts on both employees (reduce of moral and motivations, increase of exhaustion, increase of intention to leave the job, etc.) and companies (reduce of organizational loyalty and citizenship feelings, premature retirement requests, damaging organizational images, etc.) just like mobbing and existed subsequently due to generally organizational reasons and another subject of the organizational behavior, reveals the need for studies on this issue, and this realized study focused on this issue.

\section{Research hypothesis}

Mobbing, which is faced commonly in business life, has negative effects on employees, organization and also social structures. Studies show that an organizational culture, where humanitarian and healthy working conditions are lost, and forming a base for negative behaviors such as mobbing, would not motivate employee positively but on the contrary, would cause alienation process to commence, to increase work dissatisfaction and trigger intention to leave the job, destroy organizational trust, reduce organizational and job loyalty, increase compensation suits, as well as employees might show cynic behaviors against their organizations, loss of credibility and client as well as reduce on competition power and consequently cause and organizational entropy (Einarsen, 2000; Zapf et.al., 1996; Nield, 1996; Leymann, 1996; Kalay and Oğrak, 2012).

When reasons, causing organizational cynicism are listed in the literature, various belief, affect and behavior factors can be listed, of which leading ones of these are violations of psychological contract, believed to be between employee and organization, unbalanced distribution of the power, injustice, classical business methods and values, very long working hours, mobbing, bad management, ineffective leadership, organizational reducing, restructuring, firing managers, high manager fees, suddenly and mercilessly performed firings, 
low organizational performance and organizational change (Andersson and Bateman, 1997; Eaton, 2000; Fitzgerald, 2002; Cartwright and Holmes, 2006; Byrne and Hochwarter, 2007; Özgener et.al., 2008; Gül and Ağıröz, 2011). Besides, it is determined that organizational cynicism, which is experienced in the organizations, has effect on emotional exhaustion, work satisfaction, discontinuity to the work, resistance to organizational change efforts, exhaustion, alienation, work performance, work motivation, organizational trust and organizational loyalty (Andersson and Bateman, 1997; Abraham, 2000; Maslach, 2003; Pugh, et.al., 2003; Stanley et.al., 2005; Pelit and Ayduğan 2011; Kalay and Oğrak, 2012; Özgan et.al., 2012). Having production of human at the center of hotels increase the possibility of affection from various events (harassment, violence, etc.), experienced within the organization, and thus, this condition might reflect to the attitudes of the employees against the organization. At this point, mobbing actions, exist in these kind of organizations where human relations are intensely experienced, are occurring more distinctly (Avcı and Kaya, 2010; Pelit and Kılıç, 2012).

Although studies, which are submitted on the previous sections of the study in connection with the impacts of mobbing at both personal and organizational level, include findings, showing that this event causes negative results on all companies, with the service companies having the leading role, one can realize that studies are lacking in connection with impacts mobbing on the organizational cynicism, an unwanted condition for organizations. Such as, no study is faced, which reveals this relation level in connection with tourism hotels. However, stages and processes, which are included by the mobbing, are mainly including the factors, which will cause persons to develop organizational cynicism. In this respect, hypothesis of this study, which is based on the aim to determine impact of hotels' employees' mobbing perceptions on organizational cynicism, is developed as follows;

Hypothesis: There is a positive correlation between hotel employees' mobbing perceptions and their attitudes related with organizational cynicism (mobbing increases the organizational cynicism).

\section{Methodology}

In order to find out the attitudes of the employees related with the organizational cynicism, the organizational cynicism scale developed by Dean et. al, which is also used in different studies (Brandes et..; 1999; Fitzgerald, 2002; Brandes and Das, 2005, Brandes et. al., 2006; Efilti et. al., 2008; Kalağan, 2009; Tükeltürk et. al., 2009; Arabacı, 2010; Çalışkan and Erim, 2010; Güzel et. al., 2010; Altınöz et. al., 2011) and conceptualized as three factors (belief, affect and behaviors), is used and to determine the mobbing perceptions of the employees, "Psychological Terror Inventory (LIPT)", composed of 45 different action within the Leymann (1990: 33-34)'s mobbing typology, was used. Corresponding scales are scaled according to Likert scale of 5, and employees' high points from scales mean that they have high mobbing perceptions and organizational cynicism oriented behaviors, and obtained findings are also interpreted such.

Study plane is composed of employees of 5 star hotels within Turkey, and during study instead of whole plane, sampling is made and questionnaire is applied. In this concept, staged sampling method, where stratified and stack sampling methods are employed together, was used in the study. In connection with the information from corresponding records (Ministry of 
Culture and Tourism, 2012), 1000 employees, working for a total of 30 hotels activating within the cities where 5 star hotels are very intense throughout Turkey (Antalya, Istanbul, Muğla, Izmir, Aydin, Ankara, Afyonkarahisar), were subjected to a questionnaire. An overall of 936 questionnaires were evaluated due to 64 not evaluated questionnaires due to faulty and defective completion among the returned questionnaires. Verifying factor analysis related with the scales, employed in the study, was realized and it is tested whether corresponding scales have the same factors (sizes) with the original ones. Besides, during determination of credibility analysis of the employed scales, Cronbach's Alpha coefficient was employed.

In the study, according to the results of the factor analysis and credibility analysis in connection with mobbing and organizational cynicism scales, general credibility coefficient of mobbing scale (Cronbach's Alpha) is calculated as 0,96. According to the factor analysis, characteristic value of mobbing scale, collected under 5 factors (dimensions), is bigger than 1 , and it is determined that total variance is revealed $73,39 \%$, and besides factor loads related with statements, composing each factor, were realized between 0,432 and 0,824 . In connection with variance revealing rates on the basis of factors of mobbing scale, composed of five factors (activities on the possibilities of the person to communicate adequately, activities on the possibility of the victim to maintain social contacts, activities on the possibilities of the victim to maintain his/her personal reputation, activities on the occupational situation of the victim, activities on the physical health of the victim), it is determined that "activities on the possibilities of the victim to maintain his/her personal reputation" factor reveals $24,96 \%$ of the overall variance, second factor, "activities on the possibilities of the person to communicate adequately" dimension reveals $23,36 \%$ of the overall variance, third factor "on the occupational situation of the victim" reveals $12,16 \%$, fourth factor, "activities on the physical health of the victim" reveals 7,93\% and final factor, "activities on the possibility of the victim to maintain social contacts" dimension reveals $4,97 \%$ of the overall variance. Besides, it is revealed that scale related Bartlett's test result as well as factor analysis might be applied, $\left(\chi^{2}=28517,688 ; p<0,001\right)$, and it is determined that calculated Kaiser-Meyer-Olkin value $(K M O=0,963)$ showed that sampling volume has sufficient level.

According to the factor analysis and credibility analysis results, realized in connection with organizational cynicism scale, general credibility coefficient related with organizational cynicism scale is calculated as 0,92 . According to the factor analysis results, it is determined that characteristic value of organizational cynicism scale, collected under three factors, is bigger than 1 and reveals the 70,157 \% of overall variance, and factor loads related with statements in each factor were realized between 0,524 and 0,851 . In connection with factors based variance revealing rates of organizational cynicism scale, composed of three factors belief, affect and behaviors), first dimension of the scale, belief dimension factor reveals $26,72 \%$ of the overall variance, affect dimension reveals $25,60 \%$ and behavioral dimension reveals $17,82 \%$ of the overall variance. Result of organizational cynicism scale related Bartlett's test $(\chi 2=8318,349 ; p<0,001)$, reveals that factor analysis might be applied, and calculated Kaiser-Meyer-Olkin value $(K M O=0,930)$ determines that sampling volume is at a sufficient level.

Credibility coefficient results related with both each dimension and in general of the 
scales, employed in the study, reveal that employed scales are trustworthy. Mobbing perceptions and organizational cynicism related behaviors of the employees are described and interpreted in terms of percentage, frequency and arithmetical mean values. During determination of impacts of participants' mobbing perceptions on organizational cynicism, correlation and regression (simple and multiple linear) analysis were employed.

\section{Results}

An overall of 936 questionnaires were evaluated during study, 43,7\% of the employees, who answered the questionnaire, were female and 56,3\% of them were male. It is determined that majority was composed of $23-27$ age range $(33,4 \%)$ on the age group distribution of the employees.

When perceptions of the employees related with mobbing within the company were briefly evaluated in the study, the highest mobbing perception is determined at "activities on the possibility of the person to communicate adequately" dimension $(\overline{\mathrm{X}}=1,51)$, and this is followed by "activities on the possibilities of the victim to maintain the social contacts" ( $\overline{\mathrm{X}}=$ $1,37)$, "activities on the occupational situation of the victim" $(\bar{X}=1,36)$, "activities on the possibilities of the victim to maintain his/her personal reputation" $(\overline{\mathrm{X}}=1,32)$ and "activities on the physical health of the victim " $(\bar{X}=1,20)$ dimensions in respectively. The mean of the perceptions of questionnaire answering employees in connection with presence of mobbing events within their companies was 1,37 . It is possible to say that mobbing actions are realizing at a very low level in the hotels, where application is realized, and mostly seen as "activities on the possibilities of the person to communicate adequately" dimension, first stage of the mobbing according to the obtained findings. When behaviors of employees related with organizational cynicism are generally evaluated on the basis of dimensions, it is determined that organizational cynicism dimension with the highest mean is "behavioral cynicism" ( $\overline{\mathrm{X}}=2,09)$, and the lowest dimension mean belongs to "affect cynicism" ( $\overline{\mathrm{X}}=$ 1,67). The mean value of organizational cynicism was realized as 1,86 , and obtained result shows that cynic behaviors are present within the questionnaire participant hotels even if they are very low.

In the study, results of correlation analysis, realized in connection with the relation between mobbing and organizational cynicism's dimensions, are listed on the Table 2. When correlation coefficients on the Table 2 are investigated, it is determined that general mobbing perception of the employees highest level correlated organizational cynicism is "affect dimension" ( $r=0,562)$, and the lowest correlation is "behavioral dimension" $(r=0,469)$. In this case, it is possible to say that mobbing subjected employees are experiencing organizational cynicism in the "affect dimension" at most. 
Table 2. Correlations matrix between mobbing and organizational cynicism $(n=936)$

\begin{tabular}{|c|c|c|c|c|c|}
\hline Dimensions of Mobbing & & Belief & Affect & Behavioral & $\begin{array}{l}\text { Organisational } \\
\text { cynicism } \\
\text { (Overall) }\end{array}$ \\
\hline $\begin{array}{l}\text { Activities on the possibility of } \\
\text { the person to communuciate } \\
\text { adequately }\end{array}$ & $p$ & $\begin{array}{l}0,546^{* *} \\
0,000\end{array}$ & $0,556^{* *}$ & $0,458^{* *}$ & $0,603^{* *}$ \\
\hline $\begin{array}{l}\text { Activities on the possibilities of } \\
\text { the victim to maintain social } \\
\text { contacts }\end{array}$ & $p$ & $\begin{array}{l}0,395^{\text {** }} \\
0,000\end{array}$ & $0,429^{*}$ & $0,359^{* *}$ & $0,453^{* *}$ \\
\hline $\begin{array}{l}\text { Activities on the possibilities of } \\
\text { the victim to maintain his/her } \\
\text { personal reputation }\end{array}$ & $r$ & $\begin{array}{l}0,433^{\text {** }} \\
0,000\end{array}$ & $0,492^{* *}$ & $0,416^{* *}$ & $\begin{array}{l}0,515^{* *} \\
0,000\end{array}$ \\
\hline $\begin{array}{l}\text { Activities on the occupational } \\
\text { situation of the victim }\end{array}$ & $r$ & $\begin{array}{c}0,484^{* *} \\
0,000\end{array}$ & $\begin{array}{c}0,524^{* *} \\
0,000\end{array}$ & $\begin{array}{c}0,448^{* *} \\
0,000\end{array}$ & $\begin{array}{c}0,558^{* *} \\
0,000\end{array}$ \\
\hline $\begin{array}{l}\text { Activities on the physcial health } \\
\text { of the victim }\end{array}$ & $\begin{array}{l}r \\
p\end{array}$ & $\begin{array}{l}0,276^{\text {*** }} \\
0,000\end{array}$ & $\begin{array}{c}0,344^{* *} \\
0,000\end{array}$ & $\begin{array}{l}0,265^{\text {** }} \\
0,000\end{array}$ & $\begin{array}{l}0,339^{* *} \\
0,000\end{array}$ \\
\hline Mobbing (Overall) & $r$ & $\begin{array}{c}0,516^{\text {*** }} \\
0,000\end{array}$ & $\begin{array}{c}0,562^{\text {** }} \\
0,000\end{array}$ & $\begin{array}{c}0,469^{* *} \\
0,000\end{array}$ & $\begin{array}{c}\mathbf{0 , 6 5 3}^{* *} \\
0,000\end{array}$ \\
\hline
\end{tabular}

$* * * p<0,001$

Mobbing dimension, mostly correlated with the belief, affect, behaviors and general organizational cynicism of the employees, was "activities on the possibilities of the person to communicate adequately" ( $r=0,603)$, second one was "activities on the occupational situation of the victim" $(r=0,558)$, third one was "activities on the possibilities of the victim to maintain his/her personal reputation" $(r=0,515)$, and fourth one was "activities on the possibilities of the victim to maintain social contacts" $(r=0,453)$, and the lowest correlation was realized at "activities on physical health of the victim " $(r=0,339)$ dimension.

When findings from correlation analysis were evaluated briefly, it is determined that there is a significant correlation between mobbing and organizational cynicism $(p=0,000<$ $0,001)$. Generally correlation coefficient between variables of mobbing and organizational cynicism was realized as $r=0,653$ and it is determined that there is a positive directed and strong relation between corresponding variables $(0,60<r<0,80)$. According to Table 3, where findings in connection with impacts of mobbing lower dimensions on general organizational cynicism are given, multiple linear regression model between perceptions of employees related with mobbing lower dimensions and their behaviors related with general organizational cynicism was found significant $(F=123,549 ; p<0,001)$ and corresponding model is given on Table 3 .

According to Table 3, when $\mathrm{t}$ and $\beta \mathrm{j}$ values related with impact level of mobbing composing each dimension on organizational cynicism are inspected, it is determined that the mobbing dimension with the highest impact on organizational cynicism is "activities on the possibilities of the person to communicate adequately" ( $t=10,054 ; \beta j=0,548 ; p<0,001)$. Again, it is determined that "activities on the possibilities of the victim to maintain social contants" dimension of the mobbing has an effect on organizational cynicism, even if it is a 
small one $(t=2,294 ; \beta j=0,164 ; p<0,05)$.

Table 3. The multiple linear regression analysis regarding the correlation between mobbing and organizational cynicism $(n=936)$

\begin{tabular}{|c|c|c|c|c|c|}
\hline Independent variables & $\beta \boldsymbol{j}$ & $s(b j)$ & $t$ & $p$ & Significance \\
\hline Constant & 0,531 & 0,065 & 8,215 & 0,000 & \\
\hline $\begin{array}{l}\text { Activities on the } \\
\text { possibilities of the person } \\
\text { to communicate adequately } \\
\text { (a) }\end{array}$ & 0,548 & 0,055 & 10,054 & 0,000 & \\
\hline $\begin{array}{l}\text { Activities on the } \\
\text { possibilities of the victim } \\
\text { to maintain social contants }\end{array}$ & 0,164 & 0,054 & 2,294 & 0,023 & $\begin{array}{c}F=123,549 \\
p= \\
0,000 * * *\end{array}$ \\
\hline
\end{tabular}
(b)

\begin{tabular}{|c|c|c|c|c|}
\hline $\begin{array}{l}\text { Activities on the } \\
\text { possibilities of the victim } \\
\text { to maintain his/her } \\
\text { personal reputation (c) }\end{array}$ & 0,318 & 0,055 & 3,212 & 0,012 \\
\hline $\begin{array}{l}\text { Activities on the } \\
\text { occupational situation of } \\
\text { the victim }(d)\end{array}$ & 0,400 & 0,066 & 6,104 & 0,000 \\
\hline $\begin{array}{l}\text { Activities on the physical } \\
\text { health of the victim (e) }\end{array}$ & 0,128 & 0,061 & 2,103 & 0,036 \\
\hline
\end{tabular}
$0,128(\mathrm{e})$

Dependent variable: Organizational cynicism; *** $p<0,001 ; \quad R^{2}=0,402$

Another lower dimension of the mobbing, "Activities on the physical health of the victim" dimension shows a significant effect on the organizational cynicism $(p<0,05)$. Impact level of the above mentioned dimension on organizational cynicism realized at very low level, like previous dimension $(t=3,212 ; \beta j=0,318)$. The highest second dimension of mobbing, effecting organizational cynicism, is determined as "activities on the occupational situation of the victim" ( $t=6,104 ; \beta j=0,400 ; p<0,001)$. Lower "activities on the physical health of the victim" dimension of the mobbing is determined as the dimension with the lowest impact on organizational cynicism $(t=2,103 ; \beta j=0,128 ; p=0,036)$. Besides, when accuracy coefficient $\left(R^{2}=0,402\right)$ is considered, model describing rate of formed multiple linear regression model is determined as 0,402 . As a matter of fact, these results are showing parallelism with correlation analysis.

Results of the simple linear regression analysis, realized in connection with describing the relation between general mobbing and organizational cynicism attitudes of the employees by means of a mathematical model, are given on Table 4. According to the results from Table 4 , simple linear regression model between mobbing perceptions of employees and attitudes of employees related with organizational cynicism is found significant $(F=508,110 ; p<0,001)$. This obtained result reveals the relation between mobbing independent variable and 
dependent variable of the organizational cynicism. On the other hand, according to the simple linear regression model, found significant and formed in connection with the impact of mobbing on organizational cynicism, it is determined that $42,6 \%$ of the dependant variable of the organizational cynicism is due to independent variable, mobbing $\left(R^{2}=0,402\right)$.

Table 4. The simple linear regression analyses regarding the correlation between mobbing and organizational cynicism $(n=936)$

\begin{tabular}{|c|c|c|c|c|c|}
\hline $\begin{array}{l}\text { Independent } \\
\text { variable }\end{array}$ & $\beta j$ & $s(b j)$ & $t$ & $p$ & Significance \\
\hline Constant & 0,511 & 0,064 & 7,955 & 0,000 & \multirow[b]{2}{*}{$\begin{array}{c}F=508,110 \\
\mathrm{p}=0,000 \\
* * *\end{array}$} \\
\hline Mobbing (Overall) & 0,988 & 0,044 & 22,541 & 0,000 & \\
\hline
\end{tabular}

Organizational cynicism $=0,511+0,988$ (mobbing); dependent variable:
Organizational cynicism; $* * * p<0,001 ; \quad R^{2}=0,426$

In this respect, study model, developed in compliance with the basic hypothesis of the study, found significant according to the findings from correlation and regression analysis. In other words, when mobbing perceptions of the employees increase, their organizational cynicism intended behaviors also increase. These obtained findings reveals that mobbing is effective on organizational cynicism and supports the study hypothesis, developed as "when mobbing perceptions of the employees of hotels increase, their organizational cynicism intended behaviors also increase" in connection with the aim of the study.

\section{Conclusion and Implications}

Especially thoughts of increasing competition and reducing costs in the hotels, where positive image and high quality service is mostly depending on the employee satisfaction, increase on employee turnover rate and excessiveness of labor request, to be employed in these companies, can be counted among the important reasons, which cause mobbing concept to occur. Removal or minimization of this condition has vital importance for the continuity of the company. Especially for the tourism companies, where one on one relations with customers are performed, although mobbing attitudes mostly affect the victim individual, whereas it also affects other employees, company and customer with reduce on service quality. In this respect, ignoring presence of mobbing or failure to prevent environments, where it can occur, shall prepare the ground for increasing the attitudes of employees in connection with organizational cynicism in the future, and reducing job satisfactions and loyalties as well as occurrence of bigger problems (quitting jobs by victims, getting psychological treatment, increasing employee turnover rate, reducing service quality, damaging company image and lots of other negative impacts). Thus, employees, who suffer mobbing, shall be remedied from this condition, and it also has a vital importance to prevent mobbing events within the companies with the applicable measures, and to create an efficient and productive working environment, and also to reduce organizational cynicism, which creates negative impacts within the organizations, and to take it under control, and turning it into an advantage for companies. Accordingly, in connection with the issue, during this research, realized on the employees of the Turkish hotels; we have concluded that dimension, 
where mobbing perceptions of the employees reach to the top, is the dimension, where activities on the possibilities of the person to communicate adequately. Findings from the research reveal that employees are subjected to mobbing even at a very low degree within the hotels, where they are employed. In this respect, mobbing should be realized by managers/leaders or other officers prior to reach higher levels within the company, and required measures should be taken, and this shall facilitate the removal of mobbing before it spreads/progresses within the working environment. When studies from literature are investigated, in the studies, applied in service sector or other sectors in connection with mobbing, it can underlined that mobbing perceptions of the employees are very high, and its dimension is the activities on the possibilities of the person to communicate adequately, and the lowest is the activities on the physical health of the victim. It is also possible to obtain different findings during different studies, but it is possible to mention with the findings from this study and other studies in general that mobbing is present in the companies but not progressed till to the last stages (sexual harassment, physical damaging etc.).

When attitudes of the employees related with organizational cynicism are generally considered on the basis of dimensions, organizational cynicism dimension with the highest mean figure is the behavioral cynicism, and the lowest dimension mean figure is affect cynicism. On the other hand, in some studies from literature related with the issue, it is observed that arithmetic average value of the "belief cynicism" dimension, another dimension of the organizational cynicism is higher than the other dimensions whereas in connection with the issue, in another study, realized by Pelit and Ayduğan (2011), highest average value is faced on the "behavioral cynicism" in connection with the attitudes of employees related with organizational cynicism, just like in this study. General arithmetic average value of the organizational cynicism realized as 1,86 , and obtained result reveals that cynic attitudes are present, although they are very low, within the hotels, which participated to the questionnaire. It is very important for the employee and even for company efficiency to follow the cynic attitudes, which are present in the hotels but did not reach to the levels for possible prevention, by human resources managers or other managers/leaders, and to minimize cynic attitudes via required policies and rules whenever it is detected.

As a result of testing hypothesis of the study, it is determined that mobbing has a significant impact on organizational cynicism (positively). According to the correlation analysis results in connection with the relation between mobbing and organizational cynicism, it is determined that there is a strong and positive relation between corresponding variables ( $\mathrm{r}$ $=0,653)$. It is determined that mostly "activities on the possibilities of the person to communicate adequately" dimension mobbing perceptions are effective during cynic attitude representation of the hotel employees. It is also determined that the lowest dimension of organizational cynicism with highest level relation to the general mobbing perceptions of the employees is "affect dimension". In principle, this condition can be linked with the "psychological - emotional harassment", even employed instead of mobbing by some authors and forming the most important element of the mobbing, and it is natural the affect dimension of the organizational cynicism can be affected from this condition. In addition to this, according to the multiple linear regression analysis, it is determined that other dimensions of the mobbing (activities on the possibilities of the person to communicate adequately, 


\section{Mll Macrothink}

activities on the possibility of the victim to maintain social contacts, activities on the possibilities of the victim to maintain his/her personal reputation, activities on the occupational situation of the victim, activities on the physical health of the victim) are also effective on attitudes of the employees in connection with organizational cynicism. Related with the issue, in the study of Gül and Ağıröz (2011) in connection with determining the relation between mobbing and organizational cynicism, relation/impact between above mentioned concepts are found considerable. Thus, similar results are also obtained from this study, and it is revealed that affect dimensions of mobbing and organizational cynicism are found to be the highest relative variables. In this respect, especially when it is considered that content of mobbing includes the emotional harassment events it is possible that this relation is consistent. Gül and Ağıröz (2011) are linking with mobbing perceptions of the employees within service sector with the highest relation with affect dimension to mostly exhaustion, emotional exhaustion dimension. Excessive pressure on employees emotionally and exhaustion of emotional resources shall increase their tendencies to show cynic attitudes. Besides, along with the exhaustion of emotional resources of the employees, their experienced emotional exhaustion shall cause them to feel that they are not as successful, altruistic and responsible as they were before against organization, colleagues and the persons, they serve. Consequently, a series of negative and unproductive result can exist in connection both with employee and company, such as not going to work, being late to work, discontinuity and quitting job, and more importantly, exhausted employees might approach to their managers and colleagues with skeptical, biased and hostile attitudes, in other words, cynic attitudes. Besides, when it is considered that mobbing subjected employees exhaust emotionally and cannot work in peace, it is possible to see that they have feelings, such as discomfort, stress and worries against their companies. This shall cause a significant increase while representing cynic attitudes at affect dimension against organization. When characteristics of the mobbing subjected individuals are considered, and if we think that generally persons with missing self esteem, who are avoiding to defend his/her rights, and who are honest, in good faith, introvert and alone, are selected as targets, it is possible to expect that cynicism levels of these persons cannot reach to the affect dimension, and it can be thought that they shall walk away with emotional feelings rather than mobbing appliers and company operators. In connection with the issue, similar results are also obtained in the study, implemented by Kalay and Oğrak (2012) in connection with determining the relation between organizational silence mobbing and organizational cynicism over 240 persons within University sector, and according to the correlation analysis results, it is concluded that there is an intermediate level, positive and considerable relation between mobbing and organizational cynicism.

In order to create a healthier working environment to its employees and to minimize the possible damages of organizations, which play leading role for experiencing the mobbing and organizational cynicism concepts that cause both employees and organizations to suffer losses both financially and morally as well as exist in connection with the result of certain experiences in general (disputes, miscommunication, explicit favoring, organizational injustice etc.), mobbing perceptions of the employees and their attitudes related with organizational cynicism should be determined and preventive/prohibiting policies and 
applicable solid suggestions should be developed accordingly.

In this respect, in connection with the measures, strategies, management policies and researchers oriented suggestions, to be developed with considering the positive/negative impacts on the tourism/hotel, which are selected as application venue of the study, results should be interpreted and linked with the corresponding literature support, and besides being conscious of subject oriented corresponding parties (sector, company, manager, employee and academician/researcher) in connection with the representation of important solution suggestions both to the literature and sector shall be beneficial in order to prevent negative attitudes, to be formed by mobbing and organizational cynicism.

Please note that mobbing and organizational cynicism are including negative attitudes and exist as a resistance to the development of the organization and cause organization to experience various negative results, which might cause to lose successful and talented employees, to increase the employee turnover rate, to decrease organizational loyalty and trust, to increase discontinuities, to alienate to job and disobedience. In the hotels, an important part of the service companies, during positive affection of job satisfaction, working in peace and organizational loyalties of the employees, who are undertaking an important job during maintenance/protection of quality and image, and on the other hand, during determination and prevention or removal of the organizational problems, such as mobbing and organizational cynicism that might negatively affect their performances with reducing their motivations and efficiencies and might disturb them, companies and managers have important responsibilities. This above mentioned duties and introduction of measures/activities, which shall maintain benefits in connection with what can be done (rearrangement of working hours, formation of duty descriptions, arrangement of award and fine systems, fair fee distribution, etc.), and especially attaching importance to the issue and insisting on it, shall contribute to all parties (sector, company, manager, employee, etc.).

\section{Limitations and research avenues}

This study, which is implemented in order to determine impact of mobbing on organizational cynicism, is only implemented on the employees of five star hotels among tourism companies, it is possible to develop more unique and detailed suggestions in connection with the sector by means of comparing the obtained findings with applying the same to the different company types, such as one, two, three and four star hotels, tourism agencies, catering and beverage companies, airlines and amusement companies, other companies of the tourism sector during next studies. Besides, studying issue within different branches of service sector or different sectors (banking, healthcare, etc.) shall be beneficial in order to comparing and possibility to have different results in connection with releasing impact of mobbing on organizational cynicism.

In connection with the issue, although studies in connection with relation of other issues of the organizational attitude, such as citizenship, loyalty, job satisfaction, identification, intention to quit the job, exhaustion etc., with both mobbing and organizational cynicism can be seen on the literature, this study, which is implemented due to missing researches between these above mentioned factors that might cause negative attitudes especially according to the organization, is very important both being beneficial to both issue 
related literature and also to appliers as being one of the first studies, realized especially in the tourism sector.

When issue related literature is investigated, mostly relations of mobbing with organization climate, leadership, personality, job satisfaction, intention to quit the job, organizational citizenship, exhaustion, productivity and organization loyalty are studied, and it is seen that organizational cynicism is related with psychological contract breaches, organizational trust, organizational justice, performance, organizational support, personnel strengthening, organizational loyalty, job satisfaction, organizational identification, quitting job, etc. like organizational attitude issues, and studied on them, and it is seen beneficial to link mobbing and organizational cynicism with the other issues of the organizational attitudes, organizational alienation, exhaustion, organizational silence, organizational citizenship, favoritism/nepotism, glass ceiling like issues, which have important reflections for the organizations, and then studied.

\section{References}

Abraham, R. (2000). "Organizational Cynicism: Bases and Consequences”, Genetic, Social, and General Psychology Monographs, 126(3): 269-292.

Altınöz, M., Çöp, S. and Sığındı, T. (2011). “Algılanan Örgütsel Bağlılık ve Örgütsel Sinizm İlişkisi: Ankara'daki Dört ve Beş Yıldızlı Konaklama İşletmeleri Üzerine Bir Araştırma”, SÜ İ̈BF Sosyal ve Ekonomik Araştırmalar Dergisi, 15(21): 285-315.

Altınöz, M., Çöp, S. and Kervancı, F. (2010). "Algılanan Örgütsel Adalet ve Örgütsel Sinizm İlişkisi: Ankara'daki 4 ve 5 Yıldızlı Otel İşletmeleri Üzerine Bir Araştırma”, 11. Ulusal Turizm Kongresi Bildiri Kitab1, Kuşadası, pp. 379-397.

Andersson, M.L. and Bateman, S.T. (1997). "Cynicism in the Work Place: Some Causes and Effects”, Journal of Organizational Behavior, Vol. 18, pp. 449-470.

Andersson, M.L. (1996). "Employee Cynicism: An Examination Using a Contract Violation Framework", Human Relations, 49(11): 1395-1418.

Arabac1, I.B. (2010). "The Effects of Depersonalization and Organizational Cynicism Levels on The Job Satisfaction of Educational Inspectors", African Journal of Business Management, 4(13): 2802-2811.

Avcı, U. and Kaya, U. (2010). "Yıldırma (Mobbing) ve Kişilik İlişkisi: Hizmet Sektörü Çalışanları Üzerinde Bir Araştırma", Afyon Kocatepe Üniversitesi, I.I.B.F. Dergisi, 12(2): 51-79.

Bashir, S., Nasir, Z.M., Saeed, S. and Ahmed, M. (2011). "Breach of Psychological Contract, Perception of Politics and Organizational Cynicism: Evidence From Pakistan”, African Journal of Business Management, 5(3): 844-888.

Brandes, P. and Das, D. (2006). "Locating Behavioral Cynicism at Work: Construct Issues and Performance Implications", Employee Health, Coping and Metodologies Research in Occupational Stres and Well Being, 5: 233-266.

Brandes, P., Das, D. and Hadani, M. (2006). Organizational Cynicism A Field Examination Using Global and Local Social Excahange Relationships and Workplace Outcomes, Charlotte: Information Age Publishing.

Brandes, P., Dharwadkar, R. and Dean, W.J. (1999). "Does Organizational Cynicism Matter?: 
Employee and Supervisor Perspectives on Work Outcomes", Eastern Academy of Management Proceedings, (Outstanding Empirical Paper Award), pp. 150-153.

Brandes, P. (1997). Organizational Cynicism: Its Nature, Antecedents, and Consequences, (Dissertation of Doctor of Philosophy), University of Cincinnati, Ohio.

Byrne, Z.S. and Hochwarter, W.A. (2007). "Perceived Organizational Support and Performance Relationships Across Levels of Organizational Cynicism", Journal of Managerial Psychology, 23(1): 54-72.

Cartwright, S. and Holmes, N. (2006). "The Meaning of Work: The Challenge of Regaining Employee Engagement and Reducing Cynicism", Human Resource Management Review, 16: 199-208.

Cemaloğlu, N. (2007). “Okul Yöneticilerinin Liderlik Stilleri İle Yıldırma Arasındaki İlişki”, Hacettepe Üniversitesi Ĕ̈itim Fakültesi Dergisi, 33: 77-87.

Cook, W.W. and Medley, D.M. (1954). "Proposed Hostility and Parasaic Virtue Scales for the MMPI” Journal of Applied Psychology, 38: 414-418.

Crawshaw, L. (2009). "Workplace Bullying? Mobbing? Harassment? Distraction by a Thousand Definitions", Consulting Psychology Journal: Practice and Research, American Psychological Association, 61(3): 263-267.

Çakır, B. (2006). İş Yerindeki Yıldırma Eylemlerinin (Mobbing) İşten Ayrılmalara Etkisi Üzerine Bir Araştırma, (Yayınlanmamış Yüksek Lisans Tezi), Marmara Üniversitesi, İstanbul.

Çalışkan, C.S. and Erim, A. (2010). "Pozitif Örgütsel Davranış Değişiklikleri (POD) ile Yeni Araştırma Modelleri Kurma Arayışları: POD’nin İşe Adanmışlık, Tükenmişlik ve Sinizm Üzerine Etkileri’, 18. Ulusal Yönetim ve Organizasyon Kongresi Bildiri Kitabı, Adana, pp. 658-670.

Çalışkan, O. and Tepeci, M. (2008). "Otel İşletmelerinde Ortaya Çıkan Yıldırma Davranışlarının İş Tatmini ve İşte Kalma Niyetlerine Etkileri”, Anatolia: Turizm Araştırmaları Dergisi, 19(2): 135-148.

Çalışkan, O. (2005). Turizm İşletmelerinde Çalışanlara Yapılan Yıldırma Davranışları, (Yayınlanmamış Yüksek Lisans Tezi), Mersin Üniversitesi, Mersin.

Çarıkçı, H.İ. and Yavuz, H. (2009). "Çalışanlarda Mobbing (Psikolojik Şiddet) Algısı: Sağlık Sektörü Çalışanları Üzerinde Bir Araştırma”, Süleyman Demirel Üniversitesi Sosyal Bilimler Enstitüsü Dergisi, 10: 47-62.

Davenport, N., Schwartz, R.D. and Eliot, G.P. (2003). Mobbing İş Yerinde Duygusal Taciz (O.C. Önertoy çev.). İstanbul: Sistem Yayıncılık.

Davis, W.D. and Gardner, W.L. (2004). "Perceptions of Politics and Organizational Cynicism: An Attributional and Leader-Member Exchange Perspective", The Leadership Quarterly, 15: 439-465.

Dean, W.J., Brandes, P. and Dharwadkar, R. (1998). "Organizational Cynicism", The Academy of Management Review, 23(2): 341-352.

Delken, M. (2004). Organizational Cynicism: A Study Among Call Centers, (Dissertation of Master), University of Maastricht, Maastricht.

Demirçivi, M.B. (2008). Otel Işsletmelerinde Yıldırma Eylemlerinin İş Gören Verimliliğine Etkisi ve Insan Kaynakları Yönetimi Açısından Değerlendirilmesi, (Yayınlanmamış 
Yüksek Lisans Tezi), Gazi Üniversitesi, Ankara.

Deniz, D. and Ünsal, P. (2010). "İşyerinde Yıldırmaya Uğramada Dışadönük ve Nevrotik Kişilik Yapıları ile Cinsiyetin Rolü”, "İş Güç” Endüstri İlişkileri ve Insan Kaynakları Dergisi, 12(1): 7-22.

Deniz, D. (2007). Çalışanların Kişilik Yapıları ve Kullandıkları Ego Savunma Mekanizmaları, (Yayınlanmış Yüksek Lisans Tezi), İstanbul Üniversitesi, İstanbul.

Doğan, M.A. (2009). İlköğretim Okullarında Öğretmenlere Uygulanan Psikolojik Şiddetin (Mobbing) İş Doyumuna Etkisi: Ankara İli Sincan İlçesi Örneği, (Yayınlanmamış Yüksek Lisans Tezi), Atılım Üniversitesi, Ankara.

Eaton, A.J. (2000). A Social Motivation Approach to Organizational Cynicism (Master of Arts), York University, Toronto.

Efilti, S., Gönen, Ö.Y. and Öztürk, Ü.F. (2008). “Örgütsel Sinizm: Akdeniz Üniversitesi’nde Görev Yapan Yönetici Sekreterler Üzerinde Bir Alan Araştırması”, 7. Ulusal Büro Yönetimi ve Sekreterlik Kongresi Bildiri Kitabı, Trabzon, pp. 279- 290.

Einarsen, S. (2005). "The Nature, Causes and Consequences of Bullying at Work: The Norwegian Experience", Pistes, 7(3): 1-14.

Einarsen, S., Mikkelsen E.G. and Matthiesen, S. B. (2001). "The Psychology of Bullying at Work: Explaining the Detrimental Effects on Victims", http://eaohp.org/ Documents/Vienna\% 20papers\% 20and\% 20abstracts.pdf .

Einarsen, S. (2000). "Harassment and Bulling at Work, A Review of the Scandinavian Approach", Aggression and Violent Behavior, 5(4): 379-401.

Einarsen, S. (1999). "The Nature and Causes of Bullying at Work", International Journal of Manpower, 20(1/2): 16-27.

Einarsen, S., Matthiesen, S.B. and Skogstad, A. (1998). "Bullying, Burnout and Well-Being among Assistant Nurses”, Journal of Occupational Health and Safety, Australia and New Zealand, 14: 263-268.

Ferrari, E. (2004). "Raising Awareness On Women Victims of Mobbing", The Italian Contribution, Daphne Programme, European Commission, Preventive Measures to Fight Violance Against Children, Young People and Women. http://www.mobbingportal.com/ferrare.html, (10.09.2012).

FitzGerald, M.R. (2002). Organizational Cynicism: Its Relatıonship to Perceived Organizational Injusice and Explanatory Style, (Dissertation of Doctor of Philosophy), University of Cincinnati, Ohio.

Gül, H. and Ağıröz, A. (2011). "Mobbing ve Örgütsel Sinizm Arasındaki İlişkiler: Hemşireler Üzerinde Bir Uygulama", Afyon Kocatepe Üniversitesi, İ̈BF Dergisi, 13(2): 27-47.

Güngör, M. (2008). Çalışma Hayatında Psikolojik Taciz, (1.Baskı), İstanbul: Derin Yayınları.

Güzel, B., Perçin, Ş.N. and Tükeltürk, A.Ş. (2010). "Algılanan Örgütsel Desteğin, Örgütsel Sinizmle İlişkisi ve İşten Ayrılma Niyetine Etkileri: 4-5 Yıldızlı Otel İşletmeleri Üzerine Bir Araştırma”, 18. Yönetim ve Organizasyon Kongresi Bildiri Kitabı, Adana, pp. 912-920.

Hallberg L. and Margaretha S.K. (2006). "Health Consequences of Workplace Bullying", International Journal of Qualitative Studies on Health and Well-Being, 1: 109-119.

Heames, J. and Harvey, M. (2006). "Workplace Bullying: A Cross-Level Assessment", 
Management Decision, 44(9): 1214-1230.

Hoel, H. and Einarsen, S. (2003). "Violence at Work in Hotels, Catering and Tourism", Working Paper, Genova: International Labour Office (ILO).

Hutchinson, M., Vickers, M. H., Wilkes L. and Jackson, D. (2009). "The Worse You Behave, The More You Seem, to be Rewarded: Bullying in Nursing as Organizational Corruption", Employ Respons Rights Journal, 21: 213-229.

James, S.L.M. (2005). Antecedents and Consequences of Cynicism in Organizations: An Examination of The Potential Positive and Negative Effects On School Systems, (Dissertation of Doctor of Philosophy), The Florida State University, Florida.

Johnson, J.L. and O'Leary-Kelly, A.M. (2003). "The Effects of Psychological Contract Breach and Organizational Cynicism: Not All Social Exchange Violations Are Created Equal", Journal of Organizational Behavior, 24(5): 627-647.

Kalağan, G. and Güzeller, O.C. (2010). "Öğretmenlerin Örgütsel Sinizm Düzeylerinin İncelenmesi”, Pamukkale Üniversitesi Eğitim Fakültesi Dergisi, 27: 83-97.

Kalağan, G. (2009). Araştırma Görevlerinin Örgütsel Destek Alglları ile Örgütsel Sinizm Tutumları Arasındaki Illişki, (Yayınlanmamış Yüksek Lisans Tezi), Akdeniz Üniversitesi, Antalya.

Kalay, F. and Oğrak, A. (2012). "Örgütsel Sessizlik, Mobbing ve Örgütsel Sinizm İlişkisi: Örnek Bir Uygulama”, 20. Ulusal Yönetim ve Organizasyon Kongresi Bildiri Kitabı, İzmir, pp. 492-496.

Kanter, D.L. and Mirvis, P.H. (1989). The Cynical Americans: Living and Working in An Age of Discontent and Disillusion, San Francisco: Jossey-Bass Publisher.

Karcioğlu, F. and Akbaş, S. (2010). "İşyerinde Psikolojik Şiddet ve İş Tatmini İlişkisi", Atatürk Üniversitesi İktisadi ve İdari Bilimler Dergisi, 24(3): 139-161.

Kaya, U. (2009), İşletmelerde Yıldırma Davranışları (Mobbing): İmir'de 5 Yıldızlı Şehir Otellerinde Bir Araştırma, (Yayımlanmamış Yüksek Lisans Tezi), Muğla Üniversitesi, Muğla.

Köse, H. (2006). "Örgüt İçi İletişimde Negatif Bir Olgu: Psikolojik Yıldırma ve Sistemli Bir "Ötekileştirme" Süreci Olarak Mobbing”, 2. Ulusal Halkla İlişkiler Sempozyumu Bildiriler Kitabl, Kocaeli, pp. 281-292.

Kutanis, R.Ö. and Çetinel, E. (2009). "Adaletsizlik Algısı Sinizmi Tetikler mi?: Bir Örnek Olay”, 17. Ulusal Yönetim ve Organizasyon Kongresi Bildiri Kitabı, Eskişehir, pp. 693-699.

Leymann, H. (1996). “The Content and Development of Mobbing at Work", European Journal of Work and Organisational Psychology, 5: 165-184.

Leymann, H. (1990). "Mobbing and Psychological Terror at Workplaces", Violence and Victims, 5(2): 119-126.

Mantere, S. and Martinsuo, M. (2001). “Adopting and Questioning Strategy: Exploring The Roles of Cynicism and Dissent”, 17th EGOS - European Group for Organisation Studies Colloquium, France, pp. 1-25.

Maslach, C. (2003). "Job Burnout: New Directions in Research and Intervention", Current Directions in Psychological Science, 12(5): 189-192.

McMahon, L. (2000). "Bullying and Harassment in the Workplace", International Journal Of 
Contemporary Hospitality Management, 12(6): 384-387.

Mercan, N. (2007). Örgütlerde Mobbing’in Örgüt İklimiyle İlişkisine Yönelik Bir Araştırma. (Yayınlanmamış Yüksek Lisans Tezi), Dumlupınar Üniversitesi, Kütahya.

Mkono, M. (2010). “Zimbabwean Hospitality Students' Experiences of Sexual Harassment in The Hotel Industry", International Journal of Hospitality Management, 29: 729-735.

Namie, G. (2003). "Workplace Bullying: Escalated Incivility", Ivey Business Journal Improving the Practice of Management, November/December, pp. 1-6.

Naus, A.J.A.M. (2007). Organizational Cynicism on The Nature, Antecedents, and Consequences of Employee Cynicism Toward The Employing Organization, (Dissertation of Doctor of Philosophy), Maastricht University, Maastricht.

Niederhoffer A. (1967). Behind The Shield: The Police in Urban Society, Garden City, N.Y. : Doubleday.

Nield, K. (1996). "Mobbing at Well-Being: Economic and Personel Development Implications", European Journal of Work and Organizational Psychology, 5(2): 239-249.

Osif, B.A. (2010). "Workplace Bullying", Library Leadership \& Management, 24(4): 206-212.

Özarallı, N. and Torun, A. (2007). "Çalışanlara Uygulanan Zorbalığın Mağdurların Kişilik Özellikleri, Negatif Duygular ve İşten Ayrılma Niyetleriyle İlişkisi Üzerine Bir Araştırma", XV. Ulusal Yönetim ve Organizasyon Kongresi Bildiri Kitabı, Sakarya, pp. 938-948.

Özgan, H., Külekçi, E. and Özkan, M. (2012). "Analyzing of the Relationships Between Organizational Cynicism and Organizational Commitment of Teaching Staff", International Online Journal of Educational Sciences, 4(1): 196-205.

Özgener, Ş., Öğ̈̈t, A. and Kaplan, M. (2008). İşgören-İşveren İlişkilerinde Yeni Bir Paradigma: Örgütsel Sinizm, Özdevecioğlu, M. ve Karadal, H. (Eds.) Örgütsel Davranışta Seçme Konular: Organizasyonların Karanlık Yönleri ve Verimlilik Azaltıcı Davranışlar, İlke Yayınevi, Ankara, pp. 53-72.

Özler, E.D., Atalay, G.C. and Şahin, D.M. (2010). "Örgütlerde Sinizm Güvensizlikle mi Bulaşır?”, Organizasyon ve Yönetim Bilimleri Dergisi, 2(2): 47-57.

Pedro, M.M., Sánchez, M.I.S., Navarro, M.C.S. and Izquierdo, M.G. (2008). "Workplace Mobbing and Effects on Workers' Health", The Spanish Journal of Psychology , 11(1): 219-227.

Pelit, E. and Kılıç, İ. (2012). "Mobbing ile Örgütsel Bağl1lık İlişkisi: Şehir ve Sayfiye Otellerinde Bir Uygulama”, İsletme Araştırmaları Dergisi, 4(2): 122-140.

Pelit, E. and Ayduğan, N. (2011). "Otel İşletmeleri İşgörenlerinin Örgütsel Sinizm Tutumları Üzerine Bir Araştırma", 12. Ulusal Turizm Kongresi Bildiri Kitabı, Düzce, pp. 286-302.

Piñuel, Z.I. and Oñate C.A. (2002). "La Incidencia del Mobbing o Acoso Psicológico en el Trabajo in España, Universidad de Alcala", Lan Harremanak, 7(2): 35-62.

Pitre, J.L. (2004). Organizational Cynicism at The United States Naval Academy: An Exploratory Study, (Master of Arts), Naval Postgraduate School, California.

Poyraz, K. and Aksoy, Ş.E. (2012). "Mobbing İle Örgütsel Vatandaşlık Davranışı Arasındaki 
İlişkinin Belirlenmesi ve Kütahya İl Merkezi Özel Banka İşletmelerinde Uygulama”, Dumlupınar Üniversitesi Sosyal Bilimler Dergisi, 32(1): 183-202.

Pugh, S. D., Skarlicki, P.D. and Passell, S.B. (2003). "After The Fall: Layoff Victims Trust and Cynicism in Re-employment", Journal of Occupational and Organizational Psychology, 76(2): 201-212.

Raver, J.L. (2004). Behaviour Outcomes of Interpersonal Aggression at Work: A Mediated and Moderated Model, (Dissertation of Doctor of Philosophy), The University of Maryland, Maryland, USA.

Reichers, E.A., Wanous, P.J. and Austin, T.J. (1997). "Understanding and Managing Cynicism About Organizational Change", Academy of Management Executive, 11(1): 48-59.

Rubin, R.S., Dierdorff, E.C., Bommer, W.H. and Baldwin, T.T. (2009). "Do Leaders Reap What They Sow? Leader and Employee Outcomes of Leader Organizational Cynicism About Change", The Leadership Quarterly, 20(5): 680-688.

Sloterdijk, P. (1983). Critique of Cynical Reason, Germany: Edition Suhrkamp Verlag.

Smith, P.K., Singer, M., Hoel, H. and Cooper, C.L. (2003). "Victimization in the School and the Workplace", British Journal of Psychology, 94(2): 175-188.

Stanley, D.J., Meyer, J.P. and Topolnytsky, L. (2005). "Employee Cynicism and Resistance to Organizational Change", Journal of Business and Psychology, 19(4): 429-459.

Sürgevil, O., Fettahlıŏglu, Ö.O., Gücenmez, S., Budak, G. and Budak, G. (2007). "Belediye Çalışanlarının Duygusal Saldırıya Uğrama ve Tükenmişlik Düzeylerinin İncelenmesine Yönelik Bir Araştırma", Balıkesir Üniversitesi Sosyal Bilimler Dergisi, 17(1): 36-58.

Tehrani, N. (2004). "Bullying: A Source of Chronic Post Traumatic Stres", British Journal of Guidance and Counselling, 32(3): 357-366.

Tengilimoğlu, D., Akdemir F. and Dezieglewski S. (2010). "The Effect of The Mobbing on Organizational Commitment in Hospital: A Field Study". Journal of Social Services Research, 2: 128-141.

Tetik, S. (2010). "Mobbing Kavramı: Birey ve Örgütler Açısından Önemi”, KMÜ Sosyal ve Ekonomik Araştırmalar Dergisi, 12(18): 81-89.

Tükeltürk, A.Ş., Perçin, Ş.N. and Güzel, B. (2009). “Örgütlerde Psikolojik Kontrat İhlalleri ve Sinizm İlişkisi: 4-5 Yıldızlı Otel İşletmeleri Üzerine Bir Araştırma”, 17. Ulusal Yönetim ve Organizasyon Kongresi Bildiri Kitabı, Eskişehir, pp. 688-692.

Vance, R.J., Brooks, S.M. and Tesluk, P.E. (1996). Organizational Cynicism, Cynical Cultures and Organizational Change, Unpublished Manuscript, Center for Applied Behavioral Seciences, Pennsylvania State University.

Vartia, M. (1996), "The Sources of Bullying-Psychological Work Environment and Organizational Climate", European Journal of Work and Organizational Psychology, 5(2): 203-214.

Wanous, P.J., Reichers, E.A. and Austin, T.J. (2000). "Cynicism About Organizational Change: Measurement, Antecedents, and Correlates", Group \& Organization Management, 25(2): 132-153.

Wanous, J.P., Reichers, A.E. and Austin, J.T. (1994). "Organizational Cynicism: An Initial 
Study", Academy of Management Best Papers Proceedings, pp. 269-273.

Wilkerson, J., Evansi, R.W. and Davis, D.W. (2008). "A Test of Coworkers' Influence on Organizational Cynicism, Badmouthing and Organizational Behavior", Journal of Applied Social Psychology, 38(9): 2273-2292.

Yeşiltaş, M. and Demirçivi, M. (2009). "Yıldırma Eylemlerinin Otel Personelinin Verimliliğine Etkileri”, Ticaret Turizm Eğitim Fakültesi Dergisi, 2: 47-63.

Yılmaz, A., Özler, E.D. and Mercan, N. (2008). "Mobbing ve Örgüt İklimi ile İlişkisine Yönelik Ampirik Bir Araştırma”, Elektronik Sosyal Bilimler Dergisi, 7(26): 334-357.

Yücetürk, E.E. and Öke, M.K. (2005). "Mobbing and Bulllying: Legal Aspects Related to Workplace Bullying in Turkey", South-East Europe Review, 2: 61-70.

Zapf, D. (1999). "Organizational, Work, Group Related and Personel Causes of Mobbing / Bullying at Work", International Journal Manpower, 20(1/2): 70- 85.

Zapf, D., Knorz, C. and Kulla, M. (1996). "On the Relationship Between Mobbing Faktors and Jop Content, Social Work Environment and Health Outcomes", European Journal of Work and Organizational Psychology, 5(2): 215-237. 